\title{
Raças e Doenças: uma Relação Delicada
}

\author{
JOSUÉ LAGUARDIA ${ }^{l}$
}

TAPPER, Melbourne. In the Blood - Sickle Cell Anemia and The Politics of Race. Philadelphia: University of Pennsylvania Press, 1999. $163 \mathrm{p}$.

As idéias de que a raça é primariamente uma categoria biológica (mesmo que sempre tenha incorporado uma dimensão moral e intelectual) e de que as diferenças na saúde são geneticamente determinadas continuam a exercer forte influência no pensamento epidemiológico e da saúde pública. O modelo genético de causalidade das doenças se apóia em três pressupostos básicos: a raça é uma categoria biológica válida, os genes que determinam a raça estão vinculados aos genes que afetam a saúde e a saúde de qualquer comunidade é conseqüência da constituição genética dos indivíduos que a compõem.

Como tem sido destacado, o processo de se associar acriticamente determinadas doenças a indivíduos, em decorrência de sua caracterização racial, pode levar à hegemonia de teorias etiológicas fundadas na raça, eliminando efetivamente explicações que levem em conta fatores ambientais e comportamentais associados à classe social.

A ambigüidade fundamental presente no conceito de raça obscurece o papel que a variação genética desempenha na nossa compreensão atual de doença. Noções socialmente definidas de raça são tratadas como variáveis biológicas legítimas para estimativa do risco de determinadas doenças. O prisma do reducionismo genético tem efeitos sutis, tais como a reconceitualização da etiologia da doença, em que os genes, ao contrário dos sintomas, se tornam uma forma crítica de identificação da doença, afetando as estratégias de tratamento e prevenção.

As desordens da hemoglobina, em particular a anemia falciforme (também conhecida como siclemia ou drepanocitose), representam um revés interessante na relação problemática entre genótipo e fenótipo, em que a 
conjunção da origem histórico-geográfica dos doentes, as conseqüências sociais da racialização decorrentes da discriminação de membros de uma determinada comunidade e uma ritualização política do fenômeno biológico têm sérias implicações nas políticas de saúde direcionadas para essa doença.

O livro de Tapper busca, conforme ele mesmo assinala na introdução, identificar o que permite levar em conta a distribuição da doença em termos de raça e como a anemia falciforme, em determinados momentos, se estabeleceu como objeto de análise e alvo de intervenção, emergindo várias vezes, ao longo do século XX, na interseção de uma ampla rede de discursos médicos, genéticos, sorológicos, antropológicos, pessoais e administrativos, acerca de hibridação, tribos e cidadania. O autor cita Friedrich A. Kittler e Michel Foucault como marcos referenciais para a análise das redes de discurso nas quais busca delinear os aparatos de poder, conhecimento, armazenamento, transmissão, reprodução, treinamento, vigilância e disciplina, permitindo visualizar certos objetos, tornando-os conhecíveis, calculáveis, manipuláveis e, conseqüentemente, fazendo-os mais dóceis à administração.

No primeiro capítulo, o autor destaca o papel dos paradigmas médicos dominantes no século XX, o racialismo sócio-médico e a epidemiologia científica, na promoção da noção de peculiaridade ou diferença racial e a racialização da anemia falciforme, pela adoção, por parte da ciência médica, da noção antropológica de diferença e especificidade racial. A hereditariedade e a raça desempenharam papel importante na classificação das anemias, que por sua vez também serviram para classificar as populações em raças. As diferentes taxas de ocorrência de uma dada anemia seriam expressões inequívocas de especificidades raciais - uma geometria celular particular (forma de foice) poderia ser vista como um marcador de especificidade racial (negritude). O diagnóstico de anemia falciforme em uma pessoa identificada como branca levantava questionamentos acerca da acurácia do teste, bem como da identidade racial verdadeira do indivíduo diagnosticado, pois o que estava em jogo não era a entidade clínica, mas a pureza racial (o grau de brancura) dos corpos.

Entre reconhecer que a anemia falciforme poderia ocorrer em corpos brancos ou encontrar novas estratégias para demonstrar que havia ocorrido um cruzamento inter-racial, a ciência médica optou por este último. $\mathrm{O}$ autor mostra que a identidade racial de um corpo não é, no contexto históricogeográfico, meramente uma questão biológica a ser resolvida individualmente, mas também, de maneira sutil, uma função da contaminação à qual um corpo social inteiro poderia ter sido exposto através de contatos com corpos 
sociais diferentes de si.

Os casos de anemia falciforme em povos mediterrâneos transformaram corpos, que em outros contextos seriam categorizados como brancos, em casos limítrofes. Critérios históricos (contatos ancestrais através de guerras, migrações) e geográficos (proximidade com a África) foram introduzidos para avaliar identidade racial. A anemia falciforme desempenhou papel importante na substanciação da noção de distinção racial dos corpos brancos e negros, chegando mesmo a desestabilizar certa noção de brancura: algumas vezes um caucasiano deixava de ser um caucasiano.

No segundo capítulo, Tapper mostra a imbricação da anemia falciforme, nos anos 1940 e 1950, dentro de uma complexa rede discursiva sobre o negro, na qual as visões dos séculos XIX e XX acerca da mistura das raças e doença ganham nova proeminência e se alinham às novas disciplinas da genética clínica e antropologia biológica. A explicação para a maior prevalência da doença entre os negros norte-americanos, em contraste com a maior prevalência do traço falciforme nos negros africanos, gerou a tese de que a diferenciação biogenética dos negros norte-americanos havia ocorrido como resultado da hibridação e conseqüente degeneração biológica e genética o negro norte-americano era a prova viva dos efeitos disgênicos da mistura racial.

No contexto da nova genética dos anos 1950, como sublinha Tapper, a eugenia e a genética humana formaram um continuum, ao invés de dois campos distintos, coexistindo e mesmo se fundindo para produzir uma nova e poderosa antropologia racista, informada e autorizada pela linguagem da biologia molecular. As diferenças etnológicas e biogenéticas entre os negros norte-americanos e africanos eram explicadas, no caso dos primeiros, pelo casamento com brancos e a presença de um possível fator que desencadearia o aspecto hemolítico da doença entre eles. Na África, um complexo de genes modificadores acalmava a diátese da anemia falciforme, por serem as populações africanas menos misturadas. A anemia falciforme no negro norteamericano era, portanto, uma evidência dos efeitos patológicos da transgressão racial, na qual estava implícita a noção de raça como entidade discreta, com seu conjunto distinto de características genéticas.

No terceiro capítulo, o autor aponta para o papel central da pesquisa em anemia falciforme na África colonial e sua interface com o empreendimento administrativo de então, reescrevendo as histórias nativas. Redesenha as linhas de demarcação entre as coletividades em termos de taxas da doença e define um discurso médico colonial e pós-colonial de teor explicitamente 
eugênico e preocupado com a pureza racial e o acasalamento cruzado. A concepção de tribo foi naturalizada (ou racializada) e a anemia falciforme funcionava como um dos meios mais confiáveis de identificar as tribos, de manter e apoiar a noção de diferença tribal, mesmo quando nenhuma diferença etnológica ou política poderia ser estabelecida. Tapper chama a atenção para o impasse imposto pela tese da miscigenação na explicação da anemia falciforme nos africanos, devido à inexistência de raças distintas na África, e a solução encontrada pelos cientistas, ao apelarem para a tese hamítica, que definia alguns negros africanos como mais brancos que outros, revalidando a tese da mistura.

No quarto e último capítulo, o autor discute a transformação discursiva da anemia falciforme, no final dos anos 1950. Esta passa a ser vista como passível de gerenciamento - de um desvio incontrolável da raça para um risco genético controlável, eventualmente sujeita à administração social, com a conseqüente mudança da ênfase na herança, ancestralidade racial e adaptação para o papel da conduta pessoal e formação social na contenção ou disseminação da doença, possibilitando a articulação de uma estratégia de controle e prevenção. Com o domínio do debate político pelos direitos civis nos Estados Unidos da América dos anos 1970, o conceito de raça pouco a pouco se dissociou da biologia e da genética e foi rearticulado como um fenômeno socioeconômico, um meio pelo qual o governo poderia alcançar, regular e resgatar a população afro-americana. Tornava a doença uma tecnologia da governança e apresentava os afro-americanos como um povo com força de vontade e habilidade para agir no seu próprio interesse, transformando a subjetividade e o agenciamento dos afro-americanos em instrumentos de governo.

O manejo da anemia falciforme envolvia um tipo de cuidado intensivo do self e, por extensão, da raça, com um discurso de prevenção através da intervenção nas práticas procriativas. Os relatos pessoais da anemia falciforme tornam-se aparatos inscritivos, instrumentais, na forma específica de formações do sujeito, que neste caso foi organizado em torno da idéia de responsabilidade pessoal - tecnologia do self como estratégia de governo, em conjunção com demandas emergentes e bem-sucedidas para o "empoderamento" de parte dos afro-americanos, reconhecendo uma história de negligência da doença pelas autoridades legais e manutenção do racismo. Isto deu ao governo norte-americano a oportunidade e a resposta às demandas para reparação e cidadania plena dos afro-americanos, ampliando o escrutínio governamental e o controle sobre as comunidades afro-america- 
nas.

A anemia falciforme não representava apenas uma falha na constituição do corpo negro, mas também uma ameaça às comunidades negras urbanas. Ao articular a doença como um problema que afetava certas comunidades em lugares definidos, agravado pela própria natureza da vida urbana, assumia-se implicitamente que as questões relativas à doença se referiam à higiene (vista como regras de conduta que os indivíduos devem seguir com respeito a seus próprios corpos, para proteger o corpo social), bem como à negligência governamental (vista como uma característica da experiência afro-americana).

A área urbana veio designar o espaço onde a medicina e a política convergiam, e o governo da anemia falciforme - então definido por políticas de prevenção higiênica - pressupunha a existência de uma comunidade cujos membros estivessem prontos, dispostos e capazes de fazer uso efetivo das informações. O sucesso da prevenção dependia da participação ativa da comunidade negra. Entretanto, como frisa o autor, qualquer programa que avalia um risco tem uma dimensão eugênica, coloca um problema político na estratégia do rastreamento genético e gera acusações de genocídio e discriminação contra os negros. O programa, segundo seus críticos, estava longe de representar uma ampliação da cidadania aos afro-americanos, ao retirar do coletivo social a responsabilidade pelas condições de vida das populações negras, resumindo-se a um programa de controle populacional e planejamento familiar disfarçado, que tinha pouco a ver com o bem-estar dos negros.

Para os profissionais de saúde e estudiosos brasileiros envolvidos na formulação de políticas públicas direcionadas à situação de desigualdade em saúde que acomete as populações afro-brasileiras, o livro traz uma reflexão crítica sobre as implicações políticas e sociais na constituição de um programa de prevenção de uma doença étnica/racial cuja população-alvo, nos EUA, se constituiu em torno de termos chaves, tais como a negligência, responsabilidade pessoal, urgência e autogovernança.

Vale destacar que a importância do livro se torna ainda maior na medida em que muitos dos textos acerca do papel do Estado brasileiro na implantação de um programa de controle da anemia falciforme fazem referência à estratégia norte-americana. Não levam em conta algumas questões apontadas pelo autor sobre as possíveis falhas do governo na condução do programa de prevenção da anemia falciforme e dos pressupostos assumidos pelos condutores de tais políticas, em que a doença e o corpo cidadão negro parecem possuir existências independentes in natura, podendo ser separa- 
dos das circunstâncias políticas e sociais que os envolvem e das agendas dos envolvidos, e que políticas ideais podem ser implementadas em comunidades "reais".

\section{NOTA}

1 Mestre em Saúde Coletiva pelo IMS/UERJ e doutorando em Saúde Pública pela Escola Nacional de Saúde Pública da FIOCRUZ. 